This item was submitted to Loughborough's Research Repository by the author.

Items in Figshare are protected by copyright, with all rights reserved, unless otherwise indicated.

\title{
Environmentally sustainable practices at UK airports
}

PLEASE CITE THE PUBLISHED VERSION

http://dx.doi.org/10.1680/tran.13.00076

PUBLISHER

() ICE Publishing

VERSION

VoR (Version of Record)

LICENCE

CC BY-NC-ND 4.0

REPOSITORY RECORD

Budd, Thomas, Lucy C.S. Budd, and Stephen G. Ison. 2019. "Environmentally Sustainable Practices at UK Airports". figshare. https://hdl.handle.net/2134/17450. 


\section{Environmentally sustainable practices at UK airports}

1 Thomas Budd PhD

Teaching and Research Fellow, Centre for Air Transport

Management, Cranfield University, Cranfield, UK

2 Lucy Budd MSc, PhD

Senior Lecturer in Air Transport, Transport Studies Group, School of

Civil and Building Engineering, Loughborough University,

Loughborough, UK
3 Stephen Ison MA, Cert Ed, PhD, MCILT

Professor of Transport Policy, Transport Studies Group, School of Civil and Building Engineering, Loughborough University, Loughborough, UK
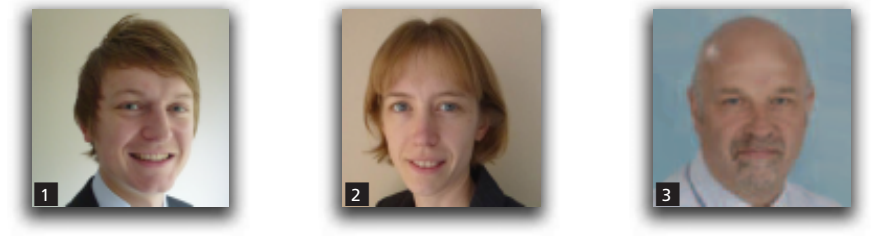

In response to growing concerns about rising energy bills, long-term energy security and the environmental impacts of greenhouse gas emissions, airport operators worldwide are increasingly implementing new sustainable practices to help reduce costs, increase efficiency and reduce their environmental impacts. These initiatives include the installation of on-site wind turbines, biomass plants, and 'smart' heating and lighting systems as well as other 'green' initiatives including rainwater harvesting initiatives, improved recycling facilities and financial incentives to encourage staff to travel to work by modes other than the private car. Drawing on specific examples, this paper examines the ways in which UK airports have responded to the challenge of reducing the environmental impacts of operations for which they are directly responsible by implementing green and sustainable energy and working practices. The paper concludes by discussing the importance of sustainable airport practices in light of future growth in key emerging aviation markets.

\section{Introduction: Airport sustainability in the UK}

The environmental impacts and implications of the aviation industry have been well documented in recent years and, as a consequence, the industry has found itself at the forefront of developments to reduce emissions and improve its environmental performance (Bows and Anderson, 2007; Upham et al., 2003). In 2012, the UK Department for Transport published a draft aviation policy framework (DfT, 2012) that sought to establish a new sustainable policy framework for UK aviation. An overarching theme of this was the need for UK airports to develop effective and innovative practices in order to facilitate growth that is simultaneously financially, socially and environmentally sustainable.

Sustainable airport practices are measures that seek to reduce environmental impacts while also creating financial and operational benefits (Lynes and Dredge, 2010). Strategies that reduce the use of raw or material resources (such as fossil fuels), lower atmospheric emissions, minimise waste production and water pollution, mitigate flooding from stormwater runoff, or protect against loss of biodiversity have the potential to yield very real, quantifiable environmental and economic benefits for airports
(Landrum \& Brown Inc. et al., 2012). A number of sustainable airport strategies in relation to named examples currently in operation at UK airports are discussed in Section 3.

Managing costs and capacity, reducing environmental impacts and emissions, while simultaneously satisfying the various and often competing demands of users and airport communities represents a major challenge for airports, and has long been recognised as a significant impediment to the future growth of the industry (de Neufville and Odoni, 2003). Notwithstanding the highly competitive and volatile nature of the industry, tackling the environmental impacts of aviation is made even more complex by the current global economic recession and ongoing constraints imposed by factors such as terrorism and the threat of the spread of infectious diseases (Warren et al., 2012). A clearer policy direction is also required in terms of airport sustainability. In particular, there is a need for policy makers to successfully reconcile issues of future shortfalls in airport capacity with often very ambitious environmental targets.

\section{Research approach}

Against this backdrop, a study of sustainable airport practices was undertaken. Data collection focused on identifying examples 
Transport

Volume 168 Issue TR2
Environmentally sustainable practices at

UK airports

Budd, Budd and Ison of sustainable practice in operation at UK airports in order to assess the ways in which airport operators have responded to the challenge of reducing the environmentally intensive nature of their operations. An important secondary objective was to place the UK experience in a wider context in comparison with airports in Europe, North America and Asia. Information was obtained from a detailed desk-based review of industry and government reports, the academic literature, airport master plans and individual airport sustainability reports. Master plans are strategic policy documents published by airports outlining their future growth and development. In addition, some airports also publish separate reports specifically addressing environmental and sustainability issues. Table 1 details the airports included in the study and the individual reports included in the desk-based review.

The UK was selected as the spatial unit of analysis for the following reasons.

(a) Size. The UK is one of the most interconnected nations worldwide. UK airports handle around 220 million passengers annually (CAA, 2012). London Heathrow airport handles the highest number of international passengers in the world and is also one of the most capacity-constrained

(www.aci.aero.com). Debates about possible future expansion are being increasingly articulated on environmental grounds. (b) Political context. The overarching theme of the UK's 2012 draft aviation policy framework (DfT, 2012) was the need for UK airports to develop effective and innovative practices in order to facilitate sustainable growth. Planning permission to expand aviation capacity in the UK is thus increasingly predicated on the provision of environmentally sustainable management practices that seek to minimise and mitigate the impact of airport operations.

(c) Data availability and reporting. UK airport master plans, airport surface access strategies and other documents are in the public domain. Airports must provide reports on their performance against set environmental targets.

The following section describes how UK airports have responded to the environmental challenges that five principal areas of operations pose before the importance of sustainable airport practices in light of future growth in key emerging aviation markets is discussed.

\section{3. 'Green' and sustainable practices at UK airports}

Table 2 details the range of sustainable practices currently implemented at UK airports. In many cases, initiatives are common to several airports, but where a certain scheme is unique to a particular site, the name of the airport is given in brackets.

\begin{tabular}{|c|c|c|c|}
\hline Airport & $\begin{array}{l}\text { Millions of } \\
\text { passengers } \\
\text { (2012 data) }\end{array}$ & Key documents & Source \\
\hline
\end{tabular}

\begin{tabular}{|c|c|c|c|}
\hline Heathrow & $70 \cdot 0$ & $\begin{array}{l}\text { Towards a Sustainable Heathrow: Sustainability Action Plan Review } \\
2011\end{array}$ & (Heathrow Airport, 2011) \\
\hline \multirow[t]{2}{*}{ Gatwick } & $34 \cdot 2$ & Gatwick Master Plan & (Gatwick Airport, 2012) \\
\hline & & Our Decade of Change: 2011 Performance & (Gatwick Airport, 2012) \\
\hline \multirow[t]{2}{*}{ Manchester } & $19 \cdot 7$ & Manchester Airport Master Plan to 2030 & $(M A G, 2008)$ \\
\hline & & Sustainability Report 2010/11 & $(M A G, 2011)$ \\
\hline \multirow[t]{2}{*}{ Stansted } & $17 \cdot 5$ & Building a Sustainable Future: Stansted Airport & (Stansted Airport, 2012) \\
\hline & & Sustainability Report 2012 & (Stansted Airport, 2012) \\
\hline London Luton & $9 \cdot 6$ & Revised Master Plan Document & (London Luton Airport, 2012) \\
\hline Edinburgh & $9 \cdot 2$ & Edinburgh Airport Master Plan & (Edinburgh Airport, 2011) \\
\hline Birmingham & $8 \cdot 9$ & $\begin{array}{l}\text { Towards 2030: Planning a Sustainable Future for Air Transport in } \\
\text { the Midlands }\end{array}$ & $\begin{array}{l}\text { (Birmingham International } \\
\text { Airport, 2007) }\end{array}$ \\
\hline Glasgow & $7 \cdot 2$ & Glasgow Airport Draft Master Plan 2011 & (Glasgow Airport, 2011) \\
\hline Newcastle & $4 \cdot 4$ & Master Plan 2030 & (Newcastle Airport, 2013) \\
\hline \multirow[t]{2}{*}{ East Midlands } & $4 \cdot 1$ & Master Plan 2006-2030 & (East Midlands Airport, 2006) \\
\hline & & Sustainability Report 2012 & (East Midlands Airport, 2012) \\
\hline Aberdeen & $3 \cdot 3$ & Aberdeen International Airport Master Plan & (Aberdeen Airport, 2013) \\
\hline \multirow[t]{2}{*}{ Bournemouth } & 0.7 & The Master Plan & (Bournemouth Airport, 2007) \\
\hline & & Sustainability Report 2012 & (Bournemouth Airport, 2012) \\
\hline
\end{tabular}

Table 1. UK airports included in the study and the key reports consulted 


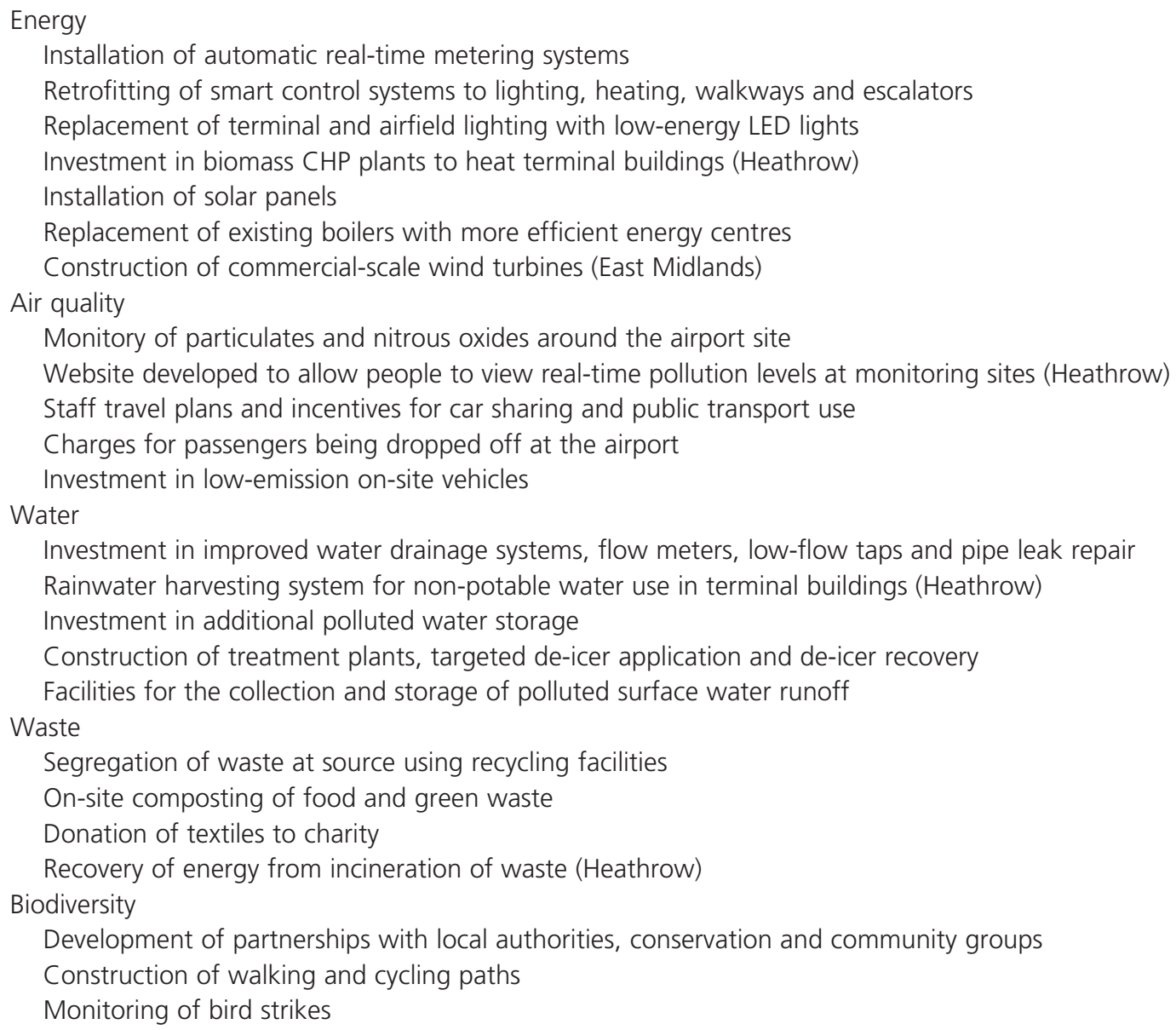

Table 2. Selected sustainable practices at UK airports

\subsection{Energy}

The scale of airport buildings combined with the overall size of airport sites means that airports are large consumers of electrical energy. Maintenance of ambient air temperature (either heating or cooling) and air quality inside terminal buildings is typically the largest source of energy consumption at airports, given the size of the buildings in question and the $24 \mathrm{~h}$ nature of operations (Ashford et al., 2013). Lighting is also a major expender of energy, both inside terminal buildings and on the airfield. The increasing commercial importance of retail facilities can also pose significant challenges in terms of energy consumption. Airport retailing is an increasingly important source of nonaeronautical revenue generation for airport operators, but it also poses a number of environmental challenges. Retailers generally demand that their products are brightly lit throughout the day to attract customers. High levels of luminance not only increase energy demands for lighting but also increase the electrical load as air conditioning is needed to remove the heat generated by these light sources.

In order to reduce electrical energy consumption and long-term operating costs, airports are placing greater emphasis on energy conservation and efficiency measures. While there has been growing emphasis on incorporating energy efficiency regimes into the design and construction of new terminal buildings in recent years, airports with existing infrastructure face challenges in terms of adapting and improving what they already have. For example, at East Midlands airport, the airport operator, Manchester Airports Group, installed an automatic electricity metering system for airport tenant companies, which provides half-hourly updates of energy consumption across the airport site (MAG, 2011). This allows airport companies to closely monitor their real-time energy use and helps the airport operator to assess patterns of energy use across the site.

The retrofitting of various systems to reduce energy consumption is also in operation at London Gatwick and Stansted airports, where 'smart' control systems are being fitted to heating and lighting systems, escalators and walkways so that they operate on-demand rather than continually. Other airports are replacing older lighting systems with more energy-efficient light-emitting diodes (LEDs). At Manchester airport, existing lights in car parks and terminal buildings have been replaced with LEDs. The airport estimates that the savings accrued from replacing the car 
Transport

Volume 168 Issue TR2
Environmentally sustainable practices at

UK airports

Budd, Budd and Ison park lights alone amount to $288 \mathrm{t}$ of carbon dioxide per year (MAG, 2011).

In an effort to reduce energy costs still further and also secure their energy supply, airports including Heathrow airport have invested in their own renewable energy generating systems. At Heathrow, a $10 \mathrm{MW}$ woodchip-fuelled combined heat and power (CHP) system was recently installed. The biomass energy plant currently provides heating and power to Terminal 5 , and will be extended to the new Terminal 2 building when it opens in 2014 (Heathrow Airport, 2011). It is estimated that the system will save $13000 \mathrm{t}$ of carbon dioxide compared with producing the same output from natural gas (www.wwf.org.uk).

Installation of solar (or photovoltaic) panels has also become relatively common at UK airports. In 2011, Bournemouth airport installed 323 photovoltaic panels on the roof of its terminal building as part of its redevelopment programme (www.bournemouthairport.com). A similar system is also in place at Birmingham airport, where 200 panels have been installed on the roof of the terminal building. It is estimated that this system will generate $40000 \mathrm{kWh} /$ year (enough to power 12 houses), which will save $22 \mathrm{t}$ of carbon dioxide per year (www.birminghamairport.co.uk). Harnessing solar energy is also common at airports in Europe and North America. For example, at Brussels airport, 7220 solar panels provide $1.7 \mathrm{MWp} /$ year, which is comparable to the annual energy consumption of 450 families, and will provide $1 \%$ of the airport's total energy consumption (www.brusselsairport.be).

Although less common, there are examples of airports installing wind turbines to harness wind energy. In 2011, two $45 \mathrm{~m}$ tall wind turbines were constructed at East Midlands airport (Figure 1). These were designed to provide $5 \%$ of the airport's electricity supply (MAG, 2011). In the USA, Boston's Logan

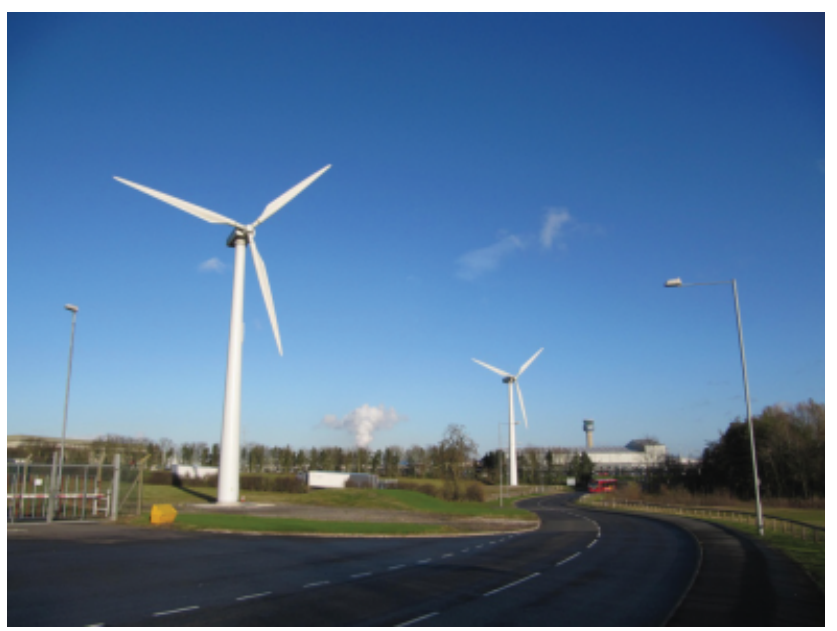

Figure 1. Wind turbines at East Midlands airport (photograph: author) airport is also one of only a small number of airports currently using wind turbines as a source of renewable energy production (www.massport.com). Reticence to adopt this technology more widely stems from safety concerns about the height of turbines relative to aircraft movements as well as their possible effects on radar systems (Tennant and Chambers, 2005).

\subsection{Air quality}

Gaseous emissions including carbon dioxide, nitrous oxides $\left(\mathrm{NO}_{\mathrm{x}}\right)$ and particulate matter from airport operations can have a significant detrimental impact on local air quality. While emissions from aircraft (either in the landing and take-off phase or taxiing) are often the largest source of emissions at an airport, surface access travel by passengers and staff, on-site vehicles and power generation also have significant impacts in terms of local air quality (Ashford et al., 2013). Consequently, UK airports typically undertake extensive monitoring regimes for measuring emissions on and around the airport site. Heathrow airport, for example, operates the Heathrow Air Watch website (www. heathrowairwatch.org.uk), which enables people to monitor levels of local air quality in real time across 19 monitoring sites on and around the airport site.

The detrimental impacts of surface access travel on air quality are easy to comprehend considering the continued reliance on private vehicles for journeys to and from airports by passengers and employees. In 2011, passenger private vehicle mode shares at the four largest airports in the UK were $58.9 \%$ (Heathrow), $57 \cdot 6 \%$ (Gatwick), $85 \cdot 6 \%$ (Manchester) and $50.9 \%$ (Stansted) (CAA, 2012). This figure is usually higher at smaller airports that cannot sustain regular public transport services (Humphreys and Ison, 2005). Private vehicle use by employees is often even higher than by passengers, as public transport networks are often illsuited to the nature of shift patterns and are generally designed to exploit airport-downtown routes, as opposed to serving residential areas (Ricard, 2012).

This can have a profound impact on air quality. At Heathrow airport, for example, it has been estimated that $80 \%$ of local air pollution results from surface access traffic and airside vehicles, with only $20 \%$ of emissions coming from aircraft (Humphreys et al., 2005). Passengers who are dropped off at the airport pose a particular challenge, given that two additional vehicle journeys to/from the airport are generated for each return flight and the number of slow and stationary vehicles on the airport site this creates. Consequently, a growing number of airports, including Luton, Birmingham, Edinburgh and East Midlands, have introduced charges for passengers to be dropped off/picked up at the terminal curbside. Unsurprisingly, these measures have proved controversial and unpopular with airport users and motoring groups (Millward, 2013). Less controversially, the majority of airports also offer schemes such as staff travel plans, car-sharing clubs and travel cards to encourage reductions in car use among employees. 
The replacement of existing ground service equipment with more fuel-efficient or low/zero emission vehicles has also taken place at a number of UK airports. In 2012, Stansted airport replaced its fleet of 'Ranger' vehicles, which are used for airside operations, with newer, more fuel-efficient vehicles. The airport estimates that this has led to a $44 \%$ reduction in emissions compared with the older vehicles. UK airports may also increasingly follow the lead set by airports such as Amsterdam's Schiphol airport, which will start using electric buses for transporting passengers to and from aircraft in 2014 (www. schiphol.nl).

\subsection{Water}

Like other large-scale industrial facilities, airports are large consumers of water. Water is needed to maintain essential services such as water for drinking, catering, retail, cleaning, flushing toilets, system maintenance and ground maintenance (Ashford et al., 2013). Consequently, water resource management and the need to reduce overall water consumption form an important part of airport management, and a number of initiatives are being pursued to reduce both water consumption and contamination. Stansted airport, for example, reduced its annual water consumption from 753 million litres in 2007 to 412 million litres in 2012. This was achieved by investing $£ 500000$ to upgrade surface water drainage pipes, pumping stations, drinking and fire water services, as well as installing flow meters and lowflow taps, pipe leak repair programmes and conducting water efficiency surveys to identify areas that could be improved still further (Stansted Airport, 2012).

At Heathrow airport's Terminal 5, a rainwater harvesting system and groundwater boreholes are used to supply the terminal's non-potable (non-drinking) water. The airport estimates that $85 \%$ of all rainwater that falls on the terminal is reused and, in combination with the boreholes, this reduces the demand on the public water supply by $70 \%$ (ACI, 2007). As well as reducing demand on conventional sources, rainwater harvesting systems can also be used as a reservoir store in case of drought or water shortage (Ashford et al., 2013). The rainwater harvesting system at Singapore Changi airport provides around a third of the airport's water needs and is estimated to save the airport operator US\$390000 (around £240000) per year (www.changiairport.com).

As well as water consumption, it is also important that airports manage water discharges from routine airport operations to prevent flooding and potential contamination of local watercourses. These include water discharges associated with aircraft maintenance and ground handling, washing aircraft on stand, airfield maintenance, winter operations and de-icing, and fire service training (Ashford et al., 2013). Without proper management, contamination of surface and groundwater sources can occur, which can be lengthy and expensive to resolve and can be potentially hazardous to plant, animal and human health.
The removal of snow and ice from aircraft and aircraft manoeuvring areas is a critical function of aircraft safety in colder climates. One effective method of de-icing aircraft is to spray the airframe with heated glycol-based fluids, but this poses an environmental problem if they reach surface or groundwater sources. Inevitably, this is more of an issue in colder climates or during sustained cold periods. At Gatwick airport, the storage and treatment capacity of de-icer-contaminated surface water runoff was exceeded following two particularly cold winters in 2009/10 and 2010/11. Consequently, measures were implemented to increase polluted water storage capacity. A new treatment plant was constructed and improved systems for targeted de-icer application and recovery were implemented (Gatwick Airport, 2012). It is common for airports to operate water storage systems for collecting contaminated water, such as those in operation at Aberdeen (Aberdeen Airport, 2013) and Stansted (Stansted Airport, 2012).

An alternative (albeit relatively expensive) option to glycol-based de-icers is infrared de-icing systems like the one currently in operation at New York's John F. Kennedy international airport. The US $\$ 9.5$ million system has reduced glycol use at the airport by $90 \%$ since it was introduced in 2006-2007, and the de-icing process is considered to be much quicker than more traditional methods (www.wingsmagazine.com). However, the airport still needs to ensure that the resulting water runoff is captured and quality assessed before discharge.

\subsection{Waste}

Airport operations also generate large quantities of solid waste. For example, Heathrow airport produces around $110000 \mathrm{t}$ of waste annually, equivalent to the volume of waste generated by all the households in a typical London borough over the same period (Heathrow Airport, 2011). Sources of waste can be divided into four main areas of airport operations: airside, terminal, landside and infrastructure development. Sustainable management of this waste inevitably involves engagement with the wide range of stakeholders and companies who produce this waste, including airlines, ground handling agents, maintenance companies and retail outlets (Ashford et al., 2013). It is common for airports to subcontract the collection and removal of waste to dedicated companies, especially in the case of hazardous material such as asbestos, radioisotopes, oils and hydraulic fluids.

In the first instance, airports will typically seek to reduce the amount of waste generated at source. This can be achieved in a variety of different ways, including bulk purchasing of materials to minimise packaging or by arranging for the return of packaging to suppliers (Ashford et al., 2013). Where waste generation is unavoidable, the reuse, recycling or recovery of energy from waste is sought in preference to waste disposal, which is generally considered to be both environmentally and economically detrimental for the airport operator. This is referred to as the waste hierarchy (Figure 2) and represents the guiding 


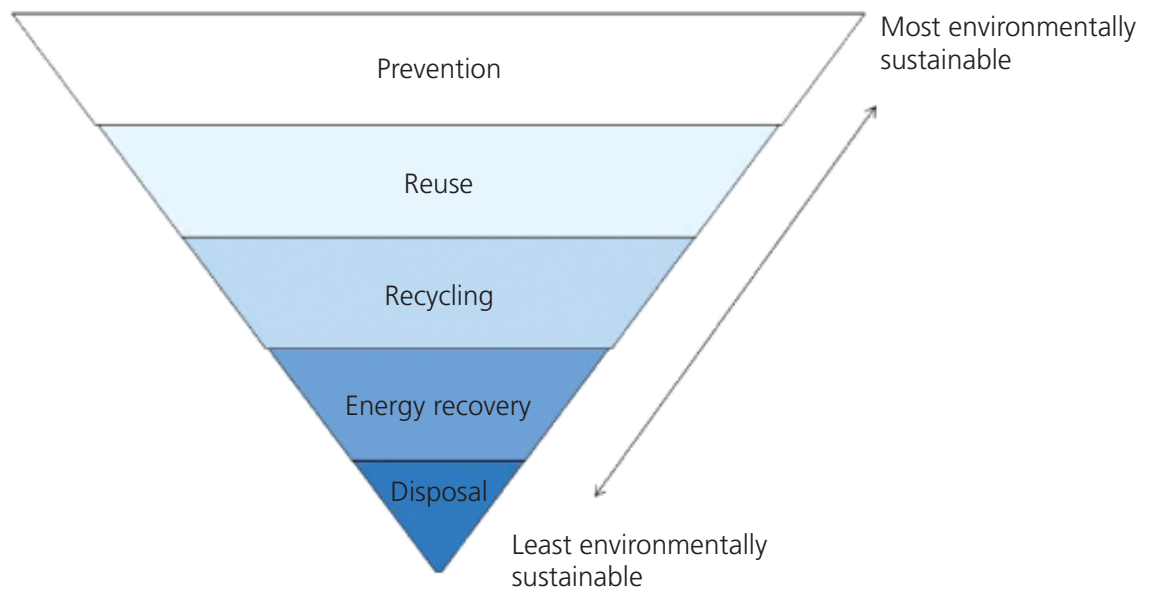

Figure 2. Waste management hierarchy (adapted from Ashford

et al., 2013)

principle of sustainable waste management at airports (Ashford et al., 2013).

As well as classifying waste according to its type and source, it is also useful to differentiate between waste that the airport operator is directly responsible for (and thus has direct control over) and waste produced by external stakeholders. Generally speaking, airport operators have the most control over waste from office administration, engineering and security operations, as well as green waste derived from airfield maintenance. An airport may have less influence over waste derived from aircraft catering and cleaning, construction or retail activities (Heathrow Airport, 2011).

Nonetheless, sustainable waste management practices will typically include the provision of mixed recycling collection facilities to ensure that as much possible waste is segregated before it is collected. This has become increasingly important given tightened airport security over recent years as directives limiting the volume of liquid passengers are permitted to carry have led to increased quantities of plastic bottles, aerosols and toiletries being left at airport security checkpoints. In addition to traditional recycling points at these locations, at Manchester and Luton airport, clothing banks have been installed so that clothes and textiles discarded by passengers wishing to reduce the weight of their luggage are donated to charity rather than sent to landfill (London Luton Airport, 2012; MAG, 2011).

For food and green waste, a number of airports operate composting facilities on the airport site. At Stansted airport, for example, $190 \mathrm{t}$ of food waste was composted in 2012. In terms of overall recycling levels, there appears to be significant progress being made. At Newcastle airport, $79 \%$ of all waste generated was diverted from landfill and recycled in 2012. The airport has set a target to reduce $100 \%$ of their waste by 2030 (Newcastle Airport, 2013).
Once the preferred options of waste reduction, reuse or recycling have been exhausted, in some cases energy can be recovered from waste via incineration. At Heathrow airport, general waste is transferred to a nearby energy-from-waste facility, where it is used to generate electricity: in 2010, $12696 \mathrm{t}$ of waste (equivalent to $51 \%$ of the waste handled via waste contracts at the airport) were sent to the facility (Heathrow Airport, 2011). Waste represents one area in which environmental and commercial objectives are increasingly aligned. Indeed, as the costs of sending waste to landfill increase, there is a commercial imperative for airports to improve their waste reduction, reuse and recycling initiatives.

\subsection{Biodiversity}

The need for easy access (both by land and by air) and the need to maintain the safety of aircraft mean that airports are designed to be unattractive to mammalian and avian pests. However, many sites are located among habitats of particular ecological value or adjacent to wildlife reserves and, as such, airports are increasingly recognising the need to minimise the adverse ecological impacts of their operations or expansion while maintaining airfield safety. This involves engaging with a wide range of stakeholders, including government bodies and agencies, local communities and wildlife groups, to implement a range of monitoring and assessment programmes to monitor and manage airport habitats and the plant and animal species within them. For example, construction of Manchester airport's second runway involved capturing and relocating protected mammalian and amphibian species away from the development.

The area around Stansted airport is also noted for its wide range of flora and fauna, including deer, brown hares and bee orchids and the ancient woodland of Hatfield Forest. The airport works with a range of landscape management experts and consultant ecologists to develop and refine a nature conservation strategy that includes the management of grassland around the runway 
and taxiways, as well as 70 ha of land close to the airport site that has specific ecological value (Stansted Airport, 2012).

In collaboration with Renfrewshire Council, Glasgow airport is involved in the conservation of Paisley Moss, a local nature reserve located adjacent to the main runway. The airport has recently developed a management plan for the reserve, which involves commitments to upgrading walking and cycling paths among other things (Glasgow Airport, 2011). A similar scheme is also in operation at East Midlands airport: with the help of volunteers, the airport established an airport trail - a walking and cycling path around the perimeter of the site (MAG, 2011).

While being mindful of their ecological impacts, it is also important that airports are able to balance these considerations with the efficient and, most importantly, safe operation of aircraft. This challenge is exemplified by the issue of birds and the threat of bird strikes, which can pose a significant hazard to aircraft (de Neufville and Odoni, 2003). It is important that measures designed to improve biodiversity do not inadvertently attract birds (or any other potentially hazardous wildlife) onto the airport site. Like other airports, at Manchester, detailed records of bird strikes are kept in order to monitor bird behaviour, identify problem species and devise species-appropriate management plans (MAG, 2011).

\section{Discussion and conclusions}

Focusing on five key areas of airport operations, this paper has examined various ways in which UK airports have responded to the challenge of reducing the environmental impacts of operations for which they are directly responsible, by implementing green and sustainable practices. To a significant degree, these were borne out of the collective need to address the growing environmental externalities of the aviation industry and the realisation that unconstrained growth was likely to be socially and environmentally unsustainable. This situation remains highly relevant and, in all likelihood, will intensify in the short to medium term in response to the changing climate, scientific breakthroughs, new regulations and legislation, increasing costs, changing public attitudes and increased demand for air travel.

It is evident that a wide range of practices is currently in operation at UK airports and there is cause for cautious optimism in that, in many cases, these are yielding immediate, significant benefits both environmentally and economically. Although admittedly not exhaustive, examples of similar practices provided in the paper show that similar measures and schemes are in operation at airports worldwide. As the number of airports adopting such measures increases over time, the scope for improvements through sharing of skills and best practice will likewise increase.

However, a word of caution should be offered as there are clearly a number of important challenges facing airports in this regard. Not least, for example, the challenging financial conditions under which airports must continue to operate following the recent economic downturn and additional financial burdens imposed by more stringent security protocols. Where possible, it is therefore important that short-term savings/benefits are not solely prioritised at the expense of strategies where the benefits may seemingly take longer to come to fruition.

This situation would be aided significantly by a much clearer, more transparent policy direction from decision makers in terms of reconciling the undoubted economic benefits of aviation and forecasted shortfalls in airport capacity, with often very ambitious environmental targets linked to greenhouse gas emissions and climate change. While there remains considerable uncertainty in this regard, what is more certain is the ongoing need for aviation to address its environmental externalities and the continuing prominence of the sustainability agenda in political and policymaking rhetoric for the foreseeable future.

It is also apparent that 'green' and sustainable airport practices are, perhaps unsurprisingly, most developed and advanced in the mature aviation markets of Western Europe, North America and selected territories in Asia (including, most notably, Hong Kong, South Korea and Singapore) where environmental consciousness and regulations regarding aviation and the environment are already well established. While it is important that this continues, it is widely considered that future growth in the industry will occur most rapidly in the emerging markets of Asia Pacific and parts of the Middle East, the Indian subcontinent and South America (Airbus, 2013; Boeing, 2013). For example, the aircraft manufacturer Boeing forecasts that, from 2013 to 2032, the Asia Pacific region will take order of nearly 13000 new aircraft. In comparison, Europe and North America are expected to receive 7460 and 7250 new aircraft respectively (Boeing, 2013). It is therefore especially important - indeed vital - that airport operators in these emerging markets are aware of the concept of sustainable aviation growth, the challenges it poses and the strategies and measures currently employed by airports to aid in achieving it.

\section{REFERENCES}

Aberdeen Airport (2013) Aberdeen International Airport Master Plan. See http://www.aberdeenairport.com/static/Aberdeen/ Downloads/PDF/AIAL-Final-Master-Plan-2013.pdf (accessed 02/10/2013).

ACl (Airports Council International) (2007) Environmental Initiatives Around the World. See http://www.enviro.aero/ Content/Upload/File/case\%20study\%20LHR_T5.pdf (accessed 14/08/2013).

Airbus (2013) Global Market Forecast 2013-2032. See http:// www.airbus.com/company/market/gmf2013/ (accessed 09/10/2013).

Ashford NJ, Stanton HPM, Moore CA, Coutu P and Beasley JR (2013) Airport Operations, 3rd edn. McGraw Hill, London, UK.

Birmingham International Airport (2007) Towards 2030: Planning a Sustainable Future for Air Transport in the 
Transport

Volume 168 Issue TR2
Environmentally sustainable practices at

UK airports

Budd, Budd and Ison
Midlands. Birmingham International Airport, Birmingham,

UK. See https://birminghamairport.co.uk/about-us/planningand-development/airport-strategy/airport-master-plan (accessed 20/09/2013).

Boeing (2013) Current Market Outlook. See http://www. boeing.com/boeing/commercial/cmo/ (accessed 09/10/2013).

Bournemouth Airport (2007) The Master Plan. Bournemouth Airport, Bournemouth, UK.

Bournemouth Airport (2012) Sustainability Report. Bournemouth Airport, Bournemouth, UK.

Bows A and Anderson KL (2007) Policy clash: Can projected aviation growth be reconciled with the UK government's $60 \%$ carbon-reduction target? Transport Policy 14(2): 103-110.

CAA (Civil Aviation Authority) (2012) CAA Passenger Survey Report 2011. See http://www.caa.co.uk/docs/81/ 2011CAAPaxSurveyReport.pdf (accessed 20/08/2013).

de Neufville R and Odoni A (2003) Airport Systems: Planning, Design and Management. McGraw Hill, New York, NY, USA.

DfT (Department for Transport) (2012) Draft Aviation Policy Framework. See https://www.gov.uk/government/uploads/ system/uploads/attachment_data/file/2739/draft-aviationpolicy-framework.pdf (accessed 11/06/2013).

East Midlands Airport (2006) Master Plan 2006-2030. East Midlands Airport, Castle Donington, UK.

East Midlands Airport (2012) Sustainability Report 2012. East Midlands Airport, Castle Donington, UK.

Edinburgh Airport (2011) Edinburgh Airport Master Plan. Edinburgh Airport, Edinburgh, UK. See https://s3-eu-west-1. amazonaws.com/edinburghairport/files/export/PDFs/ EdAir_masterplan.pdf (accessed 17/04/2015).

Gatwick Airport (2012) Gatwick Master Plan. See http:// www.gatwickairport.com/PublicationFiles/business_and_ community/all_public_publications/2012/2012-07-18gal_masterplan.pdf (accessed 20/08/2013).

Glasgow Airport (2011) Glasgow Airport Draft Master Plan 2011. Glasgow Airport, Glasgow, UK. See: http:// www.glasgowairport.com/media/37875/draft-master-planweb-small-4.pdf (accessed 09/09/2013).

Heathrow Airport (2011) Towards a Sustainable Heathrow: A Focus on Climate Change. See http://www.heathrowairport. com/static/Heathrow/Downloads/PDF/LHR_Climate_ brochure.pdf (accessed 14/08/2013).

Humphreys I and Ison S (2005) Changing airport employee travel behaviour: the role of airport surface access strategies. Transport Policy 12(1): 1-9.

Humphreys I, Ison S, Francis G and Aldridge K (2005) UK airport surface access targets. Journal of Air Transport Management 11(2): 117-124.

Landrum \& Brown Inc., Environmental Consulting Group, Inc., Primera Engineers, Ltd and Muller \& Muller Ltd (2012) Guidebook for Incorporating Sustainability into Traditional Airport Projects, ACRP Airport Corporative Research Programme. Transportation Research Board of the National Academies, Washington, DC, USA, Report 80.

London Luton Airport (2012) Revised Master Plan Document.
See http://www.london-luton.co.uk/en/content/8/1171/ Masterplan.html (accessed 20/08/2013).

Lynes JK and Dredge D (2010) Going green: motivations for environmental commitment in the airline industry. A case study of Scandinavian airlines. Journal of Sustainable Tourism 14(2): 116-138.

MAG (Manchester Airports Group) (2008) Manchester Airport Master Plan to 2030. Manchester Airports Group, Manchester, UK. See http://www.manchesterairport.co.uk/manweb.nsf/ alldocs/10F56C819A51454E8025739300388C1D/\$File/ Masterplan.pdf (accessed 13/08/2013).

MAG (2011) Sustainability Report 2010/11. The Manchester Airports Group plc, Manchester, UK.

Millward D (2013) More airports charging for 'kiss and drop'. The Daily Telegraph, 10 June.

Newcastle Airport (2013) Master Plan 2030. See http://www. newcastleairport.com/masterplan (accessed 03/10/2013).

Ricard DM (2012) Exploring Airport Employee Commute and Parking Strategies: ACRP (Airport Cooperative Research Programme) Synthesis Report 36. Transportation Research Board of the National Academies, Washington, DC, USA.

Stansted Airport (2012) Building A Sustainable Future, Stansted Airport Sustainability Report 2012. See http://www. stanstedairport.com/media/4300/sustainability_report_2013_ web_final.pdf (accessed 03/09/2013).

Tennant A and Chambers B (2005) Radar signature control of wind turbine generators. Proceedings of Antennas and Propagation Society International Symposium, Washington, DC, USA, vol. 4A, pp. 489-492.

Upham P, Maughan M, Raper D and Thomas C (2003) Towards Sustainable Aviation. Earthscan, London, UK.

Warren A, Bell M and Budd LCS (2012) Model of Health? Distributed preparedness and multi-agency interventions surrounding UK regional airports. Social Science and Medicine 74(2): 220-227.

\section{WHAT DO YOU THINK?}

To discuss this paper, please email up to 500 words to the editor at journals@ice.org.uk. Your contribution will be forwarded to the author(s) for a reply and, if considered appropriate by the editorial panel, will be published as a discussion in a future issue of the journal.

Proceedings journals rely entirely on contributions sent in by civil engineering professionals, academics and students. Papers should be $2000-5000$ words long (briefing papers should be 1000-2000 words long), with adequate illustrations and references. You can submit your paper online via www.icevirtuallibrary.com/content/journals, where you will also find detailed author guidelines. 